\title{
Doing fieldwork in Eastern Europe: fieldwork made easier
}

\author{
By Fran Deans (University College London)
}

This paper explores how the post-communist setting of my fieldwork in a Hungarian Romany settlement aided, rather than hindered, my research. Far from finding distrustful and unstable communities and institutions in post-communist Hungary, I was assisted and encouraged in my research by the supportive and open attitudes of the Romany community members and civil society actors with whom I worked. Additionally, the communist records stored in Budapest archives provided detailed data that textured and contextualised my fieldwork. With sensitive fieldwork methods, Eastern Europe is as accessible and welcoming an environment as any anthropologist could hope to find!

\section{Introduction}

The main theme of my research was to explore the reasons a micro-enterprise scheme failed to make an impact in a Romany community. In addressing this theme, I touched on topics of discrimination and poverty in a post-communist setting, local incomegeneration strategies and their place in the 'invisible' economy. I also explored expressions of Romany identity amongst Hungarian-speaking Roma (Romungro), in particular local concepts of relatedness.

As a social anthropologist, my main method of research was fieldwork, so I lived for 12 months $^{1}$ in a Romany settlement in rural, eastern Hungary where I participated in and observed daily life, and interviewed informants. As my research also included investigating the impact of a community development scheme on settlement life, I researched the non-governmental organisation (NGO) that administered the scheme. Prior to and after my fieldwork, I shadowed and interviewed NGO staff and was granted access to all files relevant to the community development projects in Epervár. ${ }^{2}$ My research allowed me to gain an understanding of the philosophy and working methods of the NGO and the attitudes and behaviour of the Romany community. My doctoral thesis contrasts the values and assumptions of the NGO with those of the community and comments on how these misunderstandings created problems in the successful implementation of the micro-enterprise scheme. It concludes with a modest proposal as to a possible way forward for organisations working in this field.

The transition from state socialism to liberal democracy was the most recent trauma to affect the Romany population of Hungary, the ramifications of which are still felt today. My anthropological fieldwork, investigating social structures and economic initiatives in a community of Hungarian Roma, was necessarily influenced by the legacy of state socialism. One might anticipate that this would cause problems for the

\footnotetext{
1 From September 2000 to September 2001.

${ }^{2}$ In an effort to protect the privacy of my informants, I have used pseudonyms when referring to places and some organisations.
} 
social science researcher, who could expect to be confronted by unstable and distrustful communities and institutions struggling to adjust to this latest upheaval. However, in terms of conducting research in this post-communist environment, I cannot say I faced any particular problems. Rather, I would suggest that the postcommunist setting of my research largely facilitated the ease of my research: I did not find a population traumatised by their (arguably) increased marginalisation, but rather found a welcoming community who, through my research, wanted to show others that they can work, want to work, and do work. In terms of collecting data, I was able to access detailed information compiled by the communist administration on the Romany population during recent decades, through Budapest-based archives and from personal sources. My research was also facilitated by the open and cooperative Hungarian civil sector which, influenced by new values based on democratic principles, responded positively to my requests.

In this paper I make three distinct points to illustrate how the state socialist legacy did not cause particular problems for my research. I begin by explaining how my research methodology offered me access to a community which one would expect to be closed to outsiders in light of their marginalisation from mainstream society. I then acknowledge the usefulness of the communist records, which provided me with a detailed picture of the living conditions of the Romany population during the state socialist period. Finally, I comment on how the open and accountable civil sector allowed me to easily access research material.

\section{Observing participant}

While some argue that increased levels of discrimination have contributed to a greater level of distrust among Roma towards mainstream society-including the curious anthropologist - I found that sensitive fieldwork methods allowed me to form close relationships with community members.

I lived in my own house in the settlement, which formed one of the far corners of the village of Epervár, but to all intents and purposes I was a member of my neighbour's household. The male head of this household provided me with interesting anecdotes and information, introduced me to key figures in the community and supported my research in every way that he could, and over time our relationship evolved to such an extent that he was heard to say that I had become like a daughter to him. Once established as a pseudo-member of this household, I was automatically affiliated to their extended family and expected to behave accordingly. However, as a researcher with ambitions of forming close relationships with as wide a sector of the community as possible, I found myself provoking my neighbours and others as I formed friendships further afield.

My role was at times catalytic in the community, and was a move away from the passive and neutral ideal of the social anthropologist as participant observer. While most anthropological fieldwork is based on participant observation, I frequently found that I was an observing participant (see Bernard 1994:138). This style of research has its drawbacks insofar as it is more difficult to analyse the situation and maintain an 'objective' stance (see Bernard 1994:152-154) when you find yourself actively involved in the everyday lives and major events of the people that you are researching. However, on a more positive note, as observing participant the researcher is perhaps better placed to access intimate information. While 'going native' is not the 
goal of anthropology, access to a relatively closed society, like the Roma, is made easier by being accepted by the community through building trust. ${ }^{3}$

This immersion into daily life was a two-way process: not only was I happy to be included so intimately in community life, I was also strongly encouraged to assimilate by members of the community. This was expressed in various ways: 'Let me cut your dress so it is nice and short', laughed a friend brandishing a pair of scissors, in an effort to get to me to dress like young unmarried ladies in the settlement; 'Of course she knows about caning, ${ }^{4}$ she came with us!' proudly exclaimed a male friend to a visitor; and again and again I would be complimented when I performed tasks such as sweeping the floor, stuffing cabbage leaves, and hoeing - not like a non-Roma (Magyar), but like one of them (Cigány). As Okely (1983:43) remarks in regard to her own fieldwork experiences, my assimilation into the community was interpreted as a show of respect.

This warm response of the community to my research should be seen against the background of the increased marginalisation that the Romany minority in Hungary is suffering from following the post-1989 transformation. Throughout the Epervár Romany settlement, the general opinion is that living standards have steadily decreased since 1989, and it is generally agreed that there has been an accompanying increase in discriminatory practices. In the following section, I describe the situation of the Roma in Hungary today. It is indisputable that Roma form one of the two poorest strata of Hungarian society ${ }^{5}$ and face discrimination at every stage of their lives: from education to justice to employment. Here, I turn to the over-lapping spheres of education and employment to illustrate the nature of the problem. By appreciating the Roma's vulnerable and marginal status, one can understand why this community may respond with hostility to mainstream society.

At every level of schooling in Hungary, Romany children drop out at a higher rate than non-Romany pupils. In secondary schools, the drop-out rate for Romany children is $40 \%$, while it is only $14 \%$ among non-Roma (Kemény, Havas and Kertesi 1996). Segregation within school is also widespread. For example, in a town near Epervár, Romany children not only had to attend separate end of year school celebrations, but in fact throughout the school year they were fed separately and forced to use separate toilets (see Bernáth and Mohács 2000, and European Roma Rights Center 1999b). While the school in Epervár is not segregated, an increasing number of non-Romany parents are choosing to send their children to schools in neighbouring towns because - as some non-Romany parents confided in me-they believe that the Romany pupils are lowering the intellectual level of the school. This trend of parents in rural locations sending their children to neighbouring schools, to avoid their children attending the local school with its significant Romany intake, is becoming more and more common (see Havas 2002:93-100). This 'white flight' leads to the 'Gypsification of schools' (Helsinki Watch 1996:67), and so sets another vicious circle in motion.

\footnotetext{
${ }^{3}$ I found MacLeod's (1995) and Whyte's (1943) accounts of their fieldwork experiences particularly informative in addressing the complexities of fieldwork in such communities.

${ }^{4}$ Caning is a winter activity involving the cutting and bundling of cane. The cane is eventually sold abroad to Germany and Holland where it is used for thatched roofs and for making furniture and fences.

${ }^{5}$ The other impoverished group is the elderly.
} 
This low level of education among Roma is one of the factors contributing to Roma's difficulty in entering the labour market. This is supported by Kertesi (2003), who concludes that low schooling, along with regional disadvantages and discrimination, contribute to the nature of unemployment among Hungarian Roma, supporting the statement that ' $[\mathrm{u}]$ nemployed Roma workers have dramatically fewer chances than non-Roma for entering or re-entering the Hungarian labour market' (UNDP 2002:32). The president of the Epervár local minority self-government estimates unemployment among the local Roma to be somewhere between 90 and $100 \%,{ }^{6}$ reflecting the general trend across the country according to NGOs. ${ }^{7}$

Many Epervár Roma say that one of the significant changes since 1989 is that employers no longer employ Roma. With former cooperatives now in private hands, employers are able to pick whom they would like to employ, and invariably it is not the Romany applicant (supported by Kertesi 2003). The abiding feeling in the settlement is that under communism there was no differentiation in the workplace based on ethnicity, whereas now there is. 'There was no such thing that this person is a Rom or whoever; he was employed. It doesn't go like that today', said one informant. It is commonly observed that Roma were the first to lose their jobs following the transition, as they were in the lowest positions within workplaces during state socialism, and remain on the margins of the workforce. Consequently, following a period of almost full employment under communism, the Romany population has now come to be defined by unemployment. It would be too simplistic to conclude that state socialism had created a utopia (consisting of employment, housing, and education) for the Hungarian Romany population. Rather, the communist policy had created a fragile structure with no solid or lasting foundation (Kállai 2002:40, Stewart 2001:86).

This rise in unemployment amongst Roma has, of course, affected poverty levels. Since 1988, poverty has increased sharply among Hungarian Roma compared to their non-Romany counterparts: 'those who report that they were not poor at all declines from $88 \%$ to $73 \%$ among non-Roma Hungarians, among Hungarian Roma the same drops from 71\% to 33\%' (Szelényi 2001:72).

This increase in poverty, the change from almost full employment to nearly total unemployment, the cessation of local youth organisations, the high rise in living costs not accompanied by a similar rise in wages and benefits, and their increased stigmatization due to skin colour are all changes that the Epervár Roma note. This sense of marginalisation is felt in small ways in daily life: Roma complain about being followed around in the shops in the village centre, they are only tolerated in one of the village pubs, and they are not comfortable walking outside the settlement unless in a group, and especially not at night without good reason and an identity card.

Against this background of increased discrimination and marginalisation from mainstream society, I could have expected a hostile and suspicious reception to my research, as I was indeed an intruding non-Rom. On an initial visit to Epervár, as in every Romany settlement I visited during my preliminary research, I was greeted by

\footnotetext{
${ }^{6}$ In Epervár there are thriving economic enterprises that are not recognised by official employment measures. Men are usually involved in some sort of business initiative, but their profit-oriented schemes fall into the shadow of formal, legal, registered business. These are the activities of the 'invisible economy'.

7 NGOs estimate that between $60-80 \%$ of Romany men and $35-40 \%$ of Romany women are unemployed, with levels soaring to 100\% in some villages (European Roma Rights Center 1999a).
} 
the familiar and slightly intimidating question: 'What are you looking for? ${ }^{8}$ In fact, the man who posed this defensive question in Epervár would soon become my main informant and greatest support in the settlement. Perhaps I presented a harmless image as a young, British woman with basic Hungarian, but the close relationships that I built over the course of my fieldwork relied on more than that, and were, I suggest, in part due to sensitive fieldwork methods that are able to overcome natural hostility to outsiders.

\section{Communist record keeping}

The communist reports that I had access to via Budapest-based archives and private sources offered a wealth of information concerning the situation of the Romany population in Hungary during the period of state socialism. This information serves as a useful background to understanding the situation of the Roma in present day Hungary, and places today's stories of declining living standards and increased instances of discriminatory practices in context.

The state socialist administration viewed the 'Gypsy problem' as a social rather than a cultural problem (in line with socialist theory), and introduced policy accordingly (see Guy 2001:3-12). Within the communist bloc during the period 1950-1986, the official strategy was the assimilation of the Roma. In order to do this, the Hungarian state socialist administration targeted specific areas in their integration programme: employment, education, housing, crime and public health. It was believed that through improving the lives of the Romany population, they could combat the ills of the capitalist system of the interwar periods that had left Roma beyond the margins of 'civilized' society. The Communist Party believed that the capitalist system had removed the opportunities of work that Roma had historically relied on in the feudal system, resulting in a rift between the Roma and non-Roma - to the detriment of the Roma (Stewart 2001:83). They therefore invested in improving the Romany population's standard of living by providing secure and proper housing (secure foundations, electricity and access to water), extending the ambition of full employment to the Roma, and targeting education, strongly encouraging Romany children to attend school through such methods as the provision of after-school care and nursery education. By improving the living conditions of the Roma, providing them with work and imbuing them with the values of the proletarian worker, it was believed that the Roma would naturally integrate into communist society.

In an effort to monitor the success of the Roma's integration and develop new strategies accordingly, the administration kept meticulous records which were compiled every five years into comprehensive reports on the situation of the population. These reports examined in turn such indicators as housing standards and school attendance, thus providing a succinct overview of the changing situation of the Roma during this period. As a researcher, I was granted access to the Budapest-based archives and was permitted to photocopy whatever information I found useful. I was also extremely fortunate to have been given copies of reports from an anonymous source, and so I was able to compile a well-informed picture of how the Romany population of Epervár lived during this period.

In order to understand the situation of the Roma in Hungary now, it is important to understand and appreciate the recent changes. The older generation of Roma in

\footnotetext{
${ }^{8}$ This somewhat hostile question in fact usually became the first words of friendly interaction.
} 
Epervár spoke of the changes in their lives that had come with the transformation, such as increased unemployment and increased levels of discrimination, as well as the cessation of the chess club and other opportunities to socialise with non-Roma. In understanding the current predicament of the Roma and their strategies of dealing with their new situation, it is important to put it in the context of the recent past - and for that the communist records are extremely useful.

\section{Civil society}

The director of the Dignity Foundation, the NGO that administered the microenterprise development scheme that I analysed, was extremely supportive of my research. She gave me access to all relevant documents, allowed me to talk freely with her and her colleagues, and let me shadow staff members. I would suggest that this deliberately open style is rooted in a firm belief in a healthy civil society, founded on such values as transparency and accountability — values that are defended as healthy alternatives to the state socialist past.

One feature of Hungary's transformation to a capitalist democracy was the state's withdrawal from welfare issues, creating a vacuum (Szalai 2003) which the civil sector partially assumed responsibility for. In an effort to fill the gap left by the state in issues of welfare, NGOs began working in a number of fields, including women's associations, youth and children, health, and Roma rights. As a result, the Hungarian civil sector has expanded rapidly to become one of the strongest in the region, with the number of NGOs growing five-fold between 1989 and 1995 to more than 43,000 registered organisations (Ringold, Orenstein and Wilkens 2003:94, citing Jenkins 1999).

It was this vacuum created by the withdrawal of the state from welfare issues that the Dignity Foundation stepped in to fill when it established itself in the early stages of the new Hungarian liberal democracy. The aim of the foundation was to effectively address the needs and desires of the Romany minority, and it was one of the first NGOs to address the economic situation of the Roma (previous assistance to Romany communities had been limited to cultural programmes and educational or social aid). Registered as an independent private foundation in 1990, the Dignity Foundation was founded by a group of ideologically minded and politically active people. The founder came from a dissident's background and, spurred by ideologies and methodologies of equality achievable through self-help initiatives, returned to Hungary as it liberalised to play a role in the emerging third sector. Other important staff members had been members of the Hungarian Foundation for Supporting the Poor (SZETA) prior to 1989. This organisation-illegal and occasionally persecuted-worked towards raising funds to distribute to the poor and, as one of the country's earliest independent organisations, it significantly contributed to the democratic opposition. The founding members of the Dignity Foundation were therefore fuelled by anti-state ideologies, determined to usher in an open democracy and an independent and effective civil society. Indeed, many of the new social and economically focused NGOs were established by anti-communist dissidents who had been active during state socialism and returning émigrés who wanted to make a positive contribution to the transition (Trehan 2001:136).

These foundations established in the immediate aftermath of state socialism therefore aimed to provide support and services according to principles and values that were 
different from the old regime (Cox and Vass 2000). In line with this, the Dignity Foundation works to address the 'failures' of the socialist state by working with the Roma on the basis of equality and partnership, under the mission statement of contributing to 'the emergence and support of civil society in Hungary', as they say in their brochure. The Dignity Foundation aims to do this through a variety of techniques, but my research focused on one particular branch of their work, namely the community development micro-enterprise schemes that formed a part of their poverty and ethnicity programme. The Dignity Foundation has transferred the ideology and aims of the micro-credit model to specifically target the Hungarian Romany community. The basic rationale of the micro-credit model is that poor, marginalised people are unable to secure loans from formal financial institutions, such as banks, and are thus denied the opportunity to engage in entrepreneurial activities. By providing small loans to such individuals, NGOs hope to redress this imbalance and, through this, to alleviate poverty, promote self-sufficiency and stimulate economic activity. By lending money to allow Romany clients to engage in smallscale income generation activities, the Dignity Foundation aims to promote social and economic autonomy for Roma. As well as providing an income to scheme participants, it is hoped that the Roma's engagement in business activities will help improve relations between Roma and non-Roma, as the non-Roma will begin to appreciate that Roma are neither lazy nor untrustworthy, thereby breaking down a few of the myths that prevail in mainstream Hungarian society.

The working practices of the Dignity Foundation emerged from and feed into the foundation's philosophy, which first and foremost believes in fostering 'horizontal' relations based on mutual trust between the foundation itself, as manifested in the contract and the monitoring process, and its clients. While my doctorate thesis explores the problematics of this approach in regard to working with Roma, who have their own specific notion of trust and different interpretations of the contract and of monitoring, for the purposes of this paper it is sufficient to note that this particular philosophy of the Dignity Foundation is part of a wider belief in civil society and in the role of NGOs in a democracy. The third sector is commonly viewed as an essential component of a modern democratic state, complementing the market economy and the government. It is seen by many to be a key component of democracy and the antithesis to state socialism. NGOs are seen to both represent and encourage civil society. The Dignity Foundation has incorporated the characteristics of a healthy civil society into its working methods: partnership, trust, accountability and transparency. With these values motivating and influencing the work methodology and attitude of the Dignity Foundation, I found it easy to access information concerning the Dignity Foundation's work in general and specifically the progress of the micro-projects in the Romany settlement of Epervár. The director and staff of the Dignity Foundation were supportive of my research, allowing me to photocopy all documents relevant to the Epervár projects, interview the director and other staff members on a number of occasions, attend conferences, and accompany monitors on their site visits.

\section{Conclusion}

As a social science researcher working in an Eastern European country, I did not find that its state socialist past and its ongoing transformation to a liberal democracy presented particular problems in terms of collecting data. Rather, I was able to access 
research material with comparative ease. I had access to detailed communist records and was assisted by open, ideologically motivated civil society actors. Most importantly, I had the support of a Romany population which was determined to show that, despite increased marginalisation, it is a dynamic and enterprising community. Potential problems can be overcome with sensitive fieldwork methods, in Eastern Europe as elsewhere.

\section{References}

Bernard, H.R. 1994. Research Methods in Anthropology: Qualitative and Quantitative Approaches. Thousand Oaks, CA: Sage Publications.

Bernáth, G. and V. Mohács. 2000. A Hajdúhadházi Roma oktatási hélyzet [The Roma educational situation in Hajdúhadház]. In their Roma Programmes in Hungary after the Transition. Unpublished manuscript. Budapest: Budapest Regional Office of the World Bank.

Cox, T. and L. Vass. 2000. Government-interest group relations in Hungarian politics since 1989. Europe-Asia Studies 52(6), 1095 -1114.

European Roma Rights Center. 1999a. Fact Sheet: Roma in Hungary (www.errc.org). . 1999b. Open letter to the Hungarian Minister of Education (www.errc.org).

Guy, W. 2001. Between Past and Future: The Roma of Central and Eastern Europe. Hertfordshire: University of Hertfordshire Press.

Havas, G. 2002. On sociological studies about the Roma. In The Gypsies/The Roma in Hungarian Society (ed.) E. Kállai. Budapest: Teleki László Foundation.

Helsinki Watch - A Division of Human Rights Watch. 1996. Rights Denied: The Roma of Hungary. New York: Human Rights Watch.

Jenkins, R. 1999. The role of the Hungarian NGO sector in postcommunist social policy. In Left Parties and Social Policy in Postcommunist Europe (eds) L. Cook, M. Orenstein and M. Rueschemeyer, 175-206. Boulder: Westview Press.

Kállai, E. 2002. The Hungarian Roma population during the last half-century. In The Gypsies/The Roma in Hungarian Society (ed.) E. Kállai, 35-50. Budapest: Teleki László Foundation.

Kemény, I., G. Havas and G. Kertesi. 1996. Representative survey on the Gypsy population in Hungary. SOCO Project Paper No. 35. Vienna: Social Consequences of Economic Transformation in East Central Europe (SOCO).

Kertesi, G. 2003. The Decline and Structural Changes of Romany Employment Between 1984 and 1994. Paper prepared for the ILO/UNDP project on Roma Labour Market Programmes in Hungary. Budapest: ILO-CEET.

MacLeod, J. 1995. Ain't No Makin' it: Aspirations and Attainment in a Low-Income Neighbourhood. Boulder, Colarado: Westview Press.

Okely, J. 1983. The Traveller-Gypsies. Cambridge: Cambridge University Press.

Ringold, D., M. Orenstein and E. Wilkens. 2003. Roma in an Expanding Europe: Breaking the Poverty Cycle. Washington, DC: World Bank. 
Stewart, M. 2001. Communist Roma policy 1945-1989 as seen through the Hungarian case. In Between Past and Future: The Roma of Central and Eastern Europe (ed.) W. Guy, 71-92. Hertfordshire: University of Hertfordshire Press.

Szalai, J. 2003. Conflicting struggles for recognition: clashing interests of gender and ethnicity in contemporary Hungary. In Recognition Struggles and Social Movements: Contested Identities, Agency and Power (ed.) B. Hobson, 188215. Cambridge: Cambridge University Press.

Szelényi, I. 2001. Poverty under post-communist capitalism-the effects of class and ethnicity in a cross-national comparison. Draft paper presented at the workshop on Culture and Poverty, Central European University, Budapest (www.ceu.hu).

Trehan, N. 2001. In the name of the Roma? The role of private foundations and NGOs. In Between Past and Future: The Roma of Central and Eastern Europe (ed.) W. Guy, 134-149. Hertfordshire: University of Hertfordshire Press.

UNDP (United Nations Development Programme). 2002. The Roma in Central and Eastern Europe: Avoiding the Dependency Trap. Bratislava: UNDP Regional Bureau for Europe and the Commonwealth of Independent States.

Whyte, W. 1943. Street Corner Society: The Social Structure of an Italian Slum. Chicago and London: University of Chicago Press.

\section{About the author}

Fran Deans was awarded a doctorate from University College London for her thesis 'Culture, community and enterprise in a Hungarian Romany settlement' (2004). She now works as a researcher for the International NGO Training and Research Centre (INTRAC) in Oxford where she continues to be involved in the fields of Roma rights and civil society. She can be contacted at frandeans@hotmail.com 